\title{
Manuscript Impact on Prognosis of Different Anatomical Hepatectomy Approaches for Single Hepatocellular Carcinoma in Segment VI
}

Jie Mei

Sun Yat-sen University Cancer Center https://orcid.org/0000-0002-5676-4216

Shao-Hua Li

Sun Yat-sen University Cancer Center

Qiao-Xuan Wang

Sun Yat-sen University Cancer Center

Liang-He Lu

Sun Yat-sen University Cancer Center

Anna Kan

Sun Yat-sen University Cancer Center

Wei Wei

Sun Yat-sen University Cancer Center

Rong-Ping Guo ( $\square$ guorp@sysucc.org.cn )

Research article

Keywords: hepatocellular carcinoma, anatomical resection, segment 6, propensity score-matching

Posted Date: September 24th, 2019

DOl: https://doi.org/10.21203/rs.2.14755/v1

License: (c) (i) This work is licensed under a Creative Commons Attribution 4.0 International License. Read Full License 


\section{Abstract}

Background. Liver resection is effective for hepatocellular carcinoma (HCC). For a single HCC in subsegment 6 (S6), segmentectomy of S6, S5 (S6+5) and segmentectomy of S6, S7 (S6+7) are the common anatomical surgical procedures. However, the benefit of the two resection methods has not been clarified in this patient subgroup. This study aimed to compare the outcomes of $\mathrm{S} 6+5$ resection and $\mathrm{S} 6+7$ resection for single, early HCC located on S6 of the liver. Methods. In total, 115 patients with single HCC in S6 without vascular invasion and distant metastasis were included in this study. The patients were divided into the $\mathbf{S} 6+5$ group $(n=73)$ and $\mathrm{S} 6+7$ group ( $n=42$ ). A one-to-one propensity score-matching analysis (PSM) was performed to minimize the effect of potential confounders. Results. Forty patients from each group were matched. The preoperative factors were balanced between the two groups. The 1-, 2-, and 3-year overall survival (OS) rates in the $\$ 6+5$ group were $92.3 \%$, $82.1 \%$, and $76.8 \%$, respectively, and in the $66+7$ group were $94.5 \%, 91.6 \%$ and $88.6 \%$, respectively $(p=0.197)$. The $1-, 2-$, and 3-year recurrence-free survival (RFS) rates in the $\mathrm{S} 6+5$ group were $71.9 \%, 61.6 \%$, and $58.9 \%$, respectively, and in the $\mathrm{S} 6+7$ group were $83.5 \%, 77.7 \%$ and $68.8 \%$, respectively $(p=0.432)$. There were no significant differences in the recurrence pattern and postoperative recovery of liver function. The surgical procedure was not a significant risk factor for the OS and RFS in both the uni- and multivariate analyses. Conclusion. S6+5 and S6+7 resection achieved similar outcomes for early-stage solitary HCC in S6.

\section{Background}

epatocellular carcinoma (HCC) is the sixth most common malignancy and the third leading cause of cancerrelated deaths worldwide[1]. Surgery is an effective treatment for early liver cancer, leading to the best outcomes of any treatment available[2]. For hepatectomy, anatomical resection was considered to have a better prognosis than non-anatomical resection in many previous studies[3-6]. However, the actual surgical procedures chosen depends on the tumour location in the liver and the intraoperative situation.

For single HCC in subsegment 6 (S6) without vascular invasion and distant metastasis, surgical resection is undoubtedly the most preferred treatment. When considering tumour factors, resection margins and liver function, the method of resection will be different. Simple $\mathbf{S 6}$ segmentectomy sometimes fails to achieve therapeutic goals. Commonly, the anatomical segmentectomy of S6 and S5 (S6+5), or segmentectomy of S6 and $S 7(S 6+7)$ will be applied, but the efficacy and benefits of segmentectomy of $S 6+5$ and $S 6+7$ remain unclear.

The purpose of the present study was to compare the true outcome of S6+5 segmentectomy with $\mathrm{S} 6+7$ segmentectomy for single, early-stage HCC in S6 using propensity score-matching (PSM) in real-world data.

\section{Methods}

This study was conducted according to the ethical guidelines of the 1975 Declaration of Helsinki. The analysis of the patient data was reviewed and approved by the Institutional Review Board at the Sun Yat-sen University Cancer Center (B2019-057-01).

\section{Patients}

From January 2006 to December 2016, a total 409 patients with single HCC limited to the liver S6 underwent liver resection as the initial treatment with curative intent at the Sun Yat-sen University Cancer Center, Department of 
Hepatobiliary Surgery, and these patients were retrospectively screened for eligibility.

Among the 409 patients, 297 were excluded from this study for the following reasons: not S6+5 or S6+7 resection (197 patients), non-anatomic resection (55 patients), pathological multiple lesions (20 patients), tumour thrombus (15 patients), extrahepatic metastasis (5 patients), and spontaneous tumour rupture (2 patients). The specific flow chart is shown in Figure 1. The remaining 115 patients were ultimately included in this study and divided into two groups: the $S 6+S 5(n=73)$ and $S 6+S 7(n=42)$ groups. All preoperative laboratory serum test was collected within 3 days before surgery. Preoperative imaging examinations included contrastenhanced computed tomography (CT) or magnetic resonance imaging (MRI) within a week before surgery.

\section{Surgical procedures}

Surgical procedures were classified according to conventional terminology derived from the eight segments[7]. Hepatic resection was performed using the previously described technique[8, 9]. Intraoperative ultrasound was routinely performed to evaluate the tumour burden, remnant liver, and possibility of a negative resection margin. Anatomical resection was defined as hepatic segmentectomy or combined resection for adjacent liver segments. Anatomical S6+5 and S6+7 segmentectomy was verified according to the surgical records.

\section{Follow-up}

Postoperative follow-up ended on May 31, 2019. The first visit of most patients after hospital discharge occurred 4 weeks after surgery. The next follow-up sessions were performed every 3 months for the first 2 years and then once every 6 months after 2 years. Each follow-up session included a detailed medical history, physical examination, laboratory tests, and one of ultrasonography, contrast-enhanced CT, or MRI. Recurrence was defined as the appearance of a new lesion with typical imaging features of HCC confirmed by at least two imaging modalities. The proper subsequent treatment was performed as clinical routine.

\section{Statistical Analysis}

The clinical characteristics between the S6+S5 and S6+S7 groups were compared. Categorical variables were compared using Pearson's $\chi 2$ test or Fisher's exact test. The variable distribution was described using the mean \pm standard error (S.E.) for normally distributed values, and median and range for non-normally distributed values. Continuous variables were compared using Student's t-test for normally distributed values or the Mann-Whitney test for skewed distributed values. To minimize the influence of selection bias produced by preoperative factors between the two groups, PSM was conducted using a logistic regression model[10,11]. Preoperative variables were entered into PSM, including age ( $\leq />50$ years old), sex (male/female), hepatitis B DNA copies $(\leq 10 \mathrm{E} 2 />10 \mathrm{E} 2), \mathrm{AFP}(\leq />400 \mathrm{ng} / \mathrm{ml})$ level, Child-Pugh score $(5 />5)$ and tumour size $(\leq 5 />5 \mathrm{~cm})$. PSM was performed by a 1:1 matching method with a calliper width of 0.1 . The survival analysis was calculated using the Kaplan-Meier method, and differences in the survival curves were analysed with the log-rank test. All variables that yielded a $\mathrm{P}$ value of $<0.1$ in the univariate analysis were subjected to a multivariate analysis using Cox's proportional hazards models. The hazard ratio $(\mathrm{HR})$ and confidence intervals $(\mathrm{Cl})$ were calculated. A value of twotailed $\mathrm{P}<0.05$ was considered statistically significant. All data analyses were performed using SPSS 25.0 (SPSS Inc., Chicago, IL).

\section{Results}




\section{Preoperative characteristics of the $\$ 6+5$ and $56+7$ groups}

The clinical preoperative characteristics of the patients in the S6+5 and S6+7 groups are summarized in Table 1. The two groups were comparable in terms of basic characteristics, liver function, tumour burden and surgical factors. After PSM, the Child-Pugh score and tumour size were more consistent in the two groups.

\section{Postoperative Survival of the S6+5 and S6+7 Groups}

In the overall cohorts, the 1-, 2-, and 3-year overall survival (OS) rates in the S6+5 group were 95.7\%, 89.9\%, and $84.9 \%$, respectively, and in the $S 6+7$ group were $94.8 \%, 92.0 \%$, and $89.2 \%$, respectively $(p=0.188)$. The $1-, 2-$, and 3 -year recurrence-free survival (RFS) rates in the $S 6+5$ group were $74.8 \%, 64.7 \%$, and $61.6 \%$, respectively, and in the $56+7$ group were $84.4 \%, 78.9 \%$ and $70.5 \%$, respectively $(p=0.288)$. In matched cohorts, the $1-, 2-$, and 3 -year OS rates in the S6+5 group were $92.3 \%, 82.1 \%$, and $76.8 \%$, respectively, and in the S6+7 group were $94.5 \%, 91.6 \%$ and $88.6 \%$, respectively ( $\mathrm{p}=0.197)$. The $1-, 2-$, and 3 -year RFS rates in the $S 6+5$ group were $71.9 \%, 61.6 \%$, and $58.9 \%$, respectively, and in the $56+7$ group were $83.5 \%, 77.7 \%$ and $68.8 \%$, respectively $(p=0.432)$. Survival graphs are shown in Figure 2. It seemed that the $\$ 6+7$ group might have better survival than the $\$ 6+5$ group, but the difference was not statistically significant.

\section{Prognostic Factors for the Overall and Recurrence-free Survival after PSM}

The risk factors of the OS and RFS were analysed using the Cox regression hazards model in matched cohorts (Table 2). The univariate analysis identified platelet (PLT) and tumour size as two significant prognostic factors for OS. Only PLT were identified as an independent prognostic predictor in the multivariate analysis (HR 0.238 , 95\% Cl 0.079-0.719, P=0.011). For RFS, Age, PLT, and tumour size were identified as independent prognostic predictors in the univariate analysis. Multivariate analysis identified age (HR 3.173, 95\% Cl 1.518-6.631, P=0.002) and tumour size (HR 4.205, 95\% Cl 2.045-8.648, $\mathrm{P}<0.001)$ as significant factors. In matched cohorts, the method of resection was not a significant predictor for OS and RFS.

\section{Postoperative Liver Function Recovery of the S6+5 and S6+7 Groups after PSM}

The serum level changes of the liver function indicators 3 days, 7 days and 1 month after the operation were compared between the $S 6+5$ and $S 6+7$ groups (Table 3 ). All indicators returned to normal over time, and there was no significant difference between the two groups.

\section{Initial Recurrence Pattern of the $56+5$ and $56+7$ Groups after PSM}

Patients with a recurrence of HCC were screened for analysis (Table 4). The initial recurrence site of the liver was as follows: surgical margin (within $2 \mathrm{~cm}$ of the cut edge), proximal part (right lobe), distal (left lobe), whole liver, and extrahepatic organ. In two of those patients, the specific recurrence sites could not be tracked until death. No significant difference in the recurrence pattern was found between the two groups.

\section{Discussion}

Clinically, HCC in segment 6 of the liver is common. Because the location is close to the edge, HCC in segment 6 tends to be easier to remove than that in other inner liver segments, which makes surgery the first choice most of the time when it is at an early stage. In the past few years, despite the controversy, anatomical resection has been 
widely applied as a rational surgical procedure for its potential ability to prevent the development of intrahepatic metastases through the portal vein[12-14]. When the tumour is small, local tumour removal or S6 anatomical resection is often used. When the tumour is large or close to the edge of the adjacent segment of the liver, the common excisional methods are the anatomical resection of $\mathbf{S 6 + 5}$ and $\mathrm{S} 6+7$. There is no previous research report on the prognosis of these two methods of resection. Therefore, we designed this study and initially showed that the two surgical procedures resulted in a similar prognosis for the HCC patients.

The baseline characteristics were almost identical in the two groups. Limited by the potential selection bias of retrospective studies, one-to-one PSM was still performed. There was no difference in survival between the $\mathbf{S 6 + 5}$ group and the $\$ 6+7$ group. It seemed that patients in the $S 6+7$ group had better data statistics for OS and RFS, but there was no significant difference. Moreover, the two resection methods had no effect on the recovery of postoperative liver function and the recurrence rate and pattern. This further verified the same prognosis in the two groups. In these early-stage HCC patients, the OS and RFS were consistent with previous scientific reports, indicating the practical universality of the patients included in this study[15-17].

In univariate and multivariate analyses, segment resection was not an independent predictor. PLTs were identified as a significant prognostic predictor for OS. This result was consistent with previous studies[18, 19]. Tumour size was reasonably the unique risk factor in the univariate and multivariate analyses for RFS. Notably, AFP and the shortest margin were not associated with survival. This might be due to the limited number of cases. However, the resection margin width had no influence on survival, according to some previous studies[20,21]. All the patients in the studies were in the early stage of HCC, with most of the tumour diameter was within 5 centimetres, which weakens the effect of AFP on the prognosis of these patients.

We acknowledge some limitations in our study. First, although PSM was used to control the imbalance of the preoperative factors, a retrospective study inevitably identifies bias. The number of cases was small. Second, the patients were selected from January 2006 to December 2016. Over a 10-year period, the technique of the surgery itself had been changed or improved. The study focused on early liver cancer patients, and the impact on the OS was relatively small. Third, our study is from a single centre. The advantage is that the perioperative management of the preoperative diagnosis, surgical technique and postoperative care is relatively consistent, which can effectively control other variables outside the scope of resection, making the conclusion credible.

\section{Conclusions}

There is no significant difference in the prognosis of patients with single, early-stage S6 HCC undergoing anatomical S6+5 segmentectomy and S6+7 segmentectomy. A reasonable surgical procedure should be chosen between the two procedures based on tumor location, liver function and safety cutting edge in routine clinical practice. The results need to be confirmed in further prospective studies.

\section{Abbreviations}

HCC, hepatocellular carcinoma; PSM, propensity score-matching; OS, overall survival; RFS, recurrence-free survival

\section{Declarations}


Informed consent statement

Patients were not required to give informed consent to the study because the analysis used anonymous clinical data that were obtained after each patient agreed verbally to undergo treatment. Individuals cannot be identified based on the data presented.

\section{Availability of data and materials}

The datasets used and/or analysed during the current study are available from the corresponding author on reasonable request.

\section{Conflicts of Interest Statement}

All authors declared no conflicts of interest.

\section{Financial support}

This research did not receive any specific grant from funding agencies in the public, commercial, or not-for-profit sectors.

\section{Authors' Contributions}

Guo RP and Wei Wei designed the study; Lu LH, Anna Kan collected the data; Wang QX analyzed and Li SH interpreted the data; Mei Jie drafted the manuscript. All authors were involved in the initial drafting, review, and approval of the manuscript and the decision to submit it for publication.

\section{Acknowledgements}

none

\section{Institutional review board statement}

This study was approved by the institutional review board (IRB) of Sun Yat-sen University Cancer Center. The approval number is B2019-057-01. The experiments were carried out in accordance with the approved guidelines.

\section{References}

1. Bray F, Ferlay J, Soerjomataram I, Siegel RL, Torre LA, Jemal A: Global cancer statistics 2018: GLOBOCAN estimates of incidence and mortality worldwide for 36 cancers in 185 countries. CA Cancer J Clin 2018, 68(6):394-424.

2. European Association for the Study of the Liver. Electronic address eee, European Association for the Study of the L: EASL Clinical Practice Guidelines: Management of hepatocellular carcinoma. J Hepato/2018, 69(1):182-236.

3. Feng X, Su Y, Zheng S, Xia F, Ma K, Yan J, Li X, Tang W, Wang S, Bie P et al: A double blinded prospective randomized trial comparing the effect of anatomic versus non-anatomic resection on hepatocellular carcinoma recurrence. HPB (Oxford) 2017, 19(8):667-674. 
4. Chen J, Huang K, Wu J, Zhu H, Shi Y, Wang Y, Zhao G: Survival after anatomic resection versus nonanatomic resection for hepatocellular carcinoma: a meta-analysis. Dig Dis Sci 2011, 56(6):1626-1633.

5. Tan Y, Zhang W, Jiang L, Yang J, Yan L: Efficacy and safety of anatomic resection versus nonanatomic resection in patients with hepatocellular carcinoma: A systemic review and meta-analysis. PLoS One 2017, 12(10):e0186930.

6. Moris D, Tsilimigras DI, Kostakis ID, Ntanasis-Stathopoulos I, Shah KN, Felekouras E, Pawlik TM: Anatomic versus non-anatomic resection for hepatocellular carcinoma: A systematic review and meta-analysis. Eur $J$ Surg Oncol 2018, 44(7):927-938.

7. Majno P, Mentha G, Toso C, Morel P, Peitgen HO, Fasel JH: Anatomy of the liver: an outline with three levels of complexity-a further step towards tailored territorial liver resections. J Hepatol 2014, 60(3):654-662.

8. Shi M, Guo RP, Lin XJ, Zhang YQ, Chen MS, Zhang CQ, Lau WY, Li JQ: Partial hepatectomy with wide versus narrow resection margin for solitary hepatocellular carcinoma: a prospective randomized trial. Ann Surg 2007, 245(1):36-43.

9. Zhang YF, Zhou J, Wei W, Zou RH, Chen MS, Lau WY, Shi M, Guo RP: Intermediate-stage hepatocellular carcinoma treated with hepatic resection: the NSP score as an aid to decision-making. Br J Cancer 2016, 115(9):1039-1047.

10. Austin PC: Optimal caliper widths for propensity-score matching when estimating differences in means and differences in proportions in observational studies. Pharm Stat 2011, 10(2):150-161.

11. Austin PC: A Tutorial and Case Study in Propensity Score Analysis: An Application to Estimating the Effect of In-Hospital Smoking Cessation Counseling on Mortality. Multivariate Behav Res 2011, 46(1):119-151.

12. Cucchetti A, Qiao GL, Cescon M, Li J, Xia Y, Ercolani G, Shen F, Pinna AD: Anatomic versus nonanatomic resection in cirrhotic patients with early hepatocellular carcinoma. Surgery 2014, 155(3):512-521.

13. Hidaka M, Eguchi S, Okudaira S, Takatsuki M, Tokai H, Soyama A, Nagayoshi S, Mochizuki S, Hamasaki K, Tajima $Y$ et al: Multicentric occurrence and spread of hepatocellular carcinoma in whole explanted end-stage liver. Hepatol Res 2009, 39(2):143-148.

14. Hokuto D, Nomi T, Yasuda S, Yoshikawa T, Ishioka K, Yamada T, Takahiro A, Nakagawa K, Nagai M, Nakamura $\mathrm{K}$ et al: Does anatomic resection improve the postoperative outcomes of solitary hepatocellular carcinomas located on the liver surface? Surgery 2018, 163(2):285-290.

15. Roayaie S, Obeidat K, Sposito C, Mariani L, Bhoori S, Pellegrinelli A, Labow D, Llovet JM, Schwartz M, Mazzaferro V: Resection of hepatocellular cancer $</=2 \mathrm{~cm}$ : results from two Western centers. Hepatology 2013, 57(4):1426-1435.

16. Tsai KY, Chen HA, Wang WY, Huang MT: Long-term and short-term surgical outcomes of laparoscopic versus open liver resection for hepatocellular carcinoma: might laparoscopic approach be better in early HCC? Surg Endosc 2019, 33(4):1131-1139.

17. Zhu Q, Yuan B, Qiao GL, Yan JJ, Li Y, Duan R, Yan YQ: Prognostic factors for survival after hepatic resection of early hepatocellular carcinoma in HBV-related cirrhotic patients. Clin Res Hepatol Gastroenterol 2016, 40(4):418-427.

18. Wang HQ, Yang J, Yang JY, Wang WT, Yan LN: Low immediate postoperative platelet count is associated with hepatic insufficiency after hepatectomy. World J Gastroenterol 2014, 20(33):11871-11877. 
19. Pang Q, Qu K, Zhang JY, Song SD, Liu SS, Tai MH, Liu HC, Liu C: The Prognostic Value of Platelet Count in Patients With Hepatocellular Carcinoma: A Systematic Review and Meta-Analysis. Medicine (Baltimore) 2015, 94(37):e1431.

20. Lee JW, Lee YJ, Park KM, Hwang DW, Lee JH, Song KB: Anatomical Resection But Not Surgical Margin Width Influence Survival Following Resection for HCC, A Propensity Score Analysis. World J Surg 2016, 40(6):14291439.

21. Sasaki K, Matsuda M, Ohkura Y, Kawamura Y, Hashimoto M, Ikeda K, Kumada H, Watanabe G: Minimum resection margin should be based on tumor size in hepatectomy for hepatocellular carcinoma in hepatoviral infection patients. Hepatol Res 2013, 43(12):1295-1303.

\section{Tables}

Table 1. Baseline characteristics and operative variables of patients before and after matching. 


\begin{tabular}{|c|c|c|c|c|c|c|}
\hline \multirow[t]{2}{*}{ Iracteristic } & \multicolumn{3}{|c|}{ ALL patients } & \multicolumn{3}{|c|}{ Propensity score-matched patients } \\
\hline & $\begin{array}{c}\text { S6+S5 Group } \\
(n=73)\end{array}$ & $\begin{array}{c}\text { S6+S7 Group } \\
(n=42)\end{array}$ & $\begin{array}{c}P \\
\text { Value }\end{array}$ & $\begin{array}{c}\text { S6+S5 Group } \\
(n=40)\end{array}$ & $\begin{array}{c}\text { S6+S7 Group } \\
(n=40)\end{array}$ & $\begin{array}{c}P \\
\text { Value }\end{array}$ \\
\hline \multicolumn{7}{|l|}{ demiology } \\
\hline ge $(y) *$ & $49.5 \pm 11.2$ & $50.2 \pm 10.1$ & 0.742 & $48.8 \pm 12.4$ & $50.8 \pm 10.0$ & 0.423 \\
\hline ender (Male/female) $* *$ & $68 / 5(93.2 / 6.8)$ & $\begin{array}{c}38 / 4 \\
(90.5 / 9.5)\end{array}$ & 0.722 & $\begin{array}{c}37 / 3 \\
(92.5 / 7.5)\end{array}$ & $\begin{array}{c}38 / 2 \\
(95.0 / 5.0)\end{array}$ & 1.000 \\
\hline \multicolumn{7}{|l|}{ iology } \\
\hline $\begin{array}{l}\text { epatitis B carrier } \\
s / \text { no) }\end{array}$ & $66 / 7(90.4 / 9.6)$ & $\begin{array}{c}39 / 3 \\
(92.9 / 7.1)\end{array}$ & 0.744 & $\begin{array}{c}38 / 2 \\
(90.0 / 10.0)\end{array}$ & $\begin{array}{c}37 / 3 \\
(92.5 / 7.5)\end{array}$ & 1.000 \\
\hline $\begin{array}{l}\text { epatitis B DNA } \\
\text { ies }(\leq 10 \mathrm{E} 2 />10 \mathrm{E} 2)\end{array}$ & $40 / 33(54.8 / 45.2)$ & $\begin{array}{c}27 / 15 \\
(64.3 / 35.7)\end{array}$ & 0.320 & $\begin{array}{c}22 / 18 \\
(55.0 / 45.0)\end{array}$ & $\begin{array}{c}25 / 15 \\
(62.5 / 37.5)\end{array}$ & 0.496 \\
\hline J performance $(0 / 1)$ & $70 / 3(95.9 / 4.1)$ & $\begin{array}{c}40 / 2 \\
(95.2 / 4.8)\end{array}$ & 1.000 & $\begin{array}{c}39 / 1 \\
(97.5 / 2.5)\end{array}$ & $\begin{array}{c}39 / 1 \\
(97.5 / 2.5)\end{array}$ & 1.000 \\
\hline \multicolumn{7}{|l|}{ ər function } \\
\hline iver cirrhosis (yes/no) & $\begin{array}{c}44 / 29 \\
(60.3 / 39.7)\end{array}$ & $\begin{array}{c}26 / 16 \\
(61.9 / 38.1)\end{array}$ & 0.863 & $\begin{array}{c}25 / 15 \\
(65.0 / 35.0)\end{array}$ & $\begin{array}{c}25 / 15 \\
(65.0 / 35.0)\end{array}$ & 1.000 \\
\hline $\begin{array}{l}\text { Thite blood cell count } \\
\left.{ }^{9} / \mathrm{L}\right) * * *\end{array}$ & $6.1(3.25-15.9)$ & $5.8(3.0-10.6)$ & 0.242 & $6.1(4.0-11.2)$ & $6.0 \pm 1.7$ & 0.296 \\
\hline aemoglobin $(\mathrm{g} / \mathrm{L})$ & $\begin{array}{c}148.0(89.0- \\
174.0)\end{array}$ & $144.5 \pm 16.0$ & 0.692 & $144.3 \pm 13.1$ & $145.6 \pm 15.6$ & 0.864 \\
\hline latelet count $\left(10^{9} / \mathrm{L}\right)$ & $184.3 \pm 57.9$ & $168.9 \pm 53.5$ & 0.164 & $179.7 \pm 54.8$ & $169.0 \pm 54.8$ & 0.377 \\
\hline rothrombin time (sec) & $11.8(10.0-15.0)$ & $11.6(9.6-14.5)$ & 0.274 & $12.2 \pm 1.1$ & $11.8 \pm 1.0$ & 0.102 \\
\hline $\begin{array}{l}\text { lanine aminotransferase } \\
\text { L) }\end{array}$ & $36.8(13.0-134.4)$ & $\begin{array}{c}38.6(9.3- \\
172.8)\end{array}$ & 0.763 & $\begin{array}{c}30.5(14.0- \\
93.4)\end{array}$ & $\begin{array}{c}38.6(9.3- \\
172.8)\end{array}$ & 0.550 \\
\hline $\begin{array}{l}\text { spartate } \\
\text { notransferase (U/L) }\end{array}$ & $30.2(15.0-109.8)$ & $\begin{array}{c}30.9(11.5- \\
115.7)\end{array}$ & 0.981 & $\begin{array}{l}28.4(15.0- \\
100.1)\end{array}$ & $\begin{array}{c}34.3(11.5- \\
115.7)\end{array}$ & 0.247 \\
\hline erum albumin $(\mathrm{g} / \mathrm{L})$ & $43.9 \pm 4.0$ & $43.3 \pm 3.3$ & 0.447 & $43.5 \pm 3.8$ & $43.5 \pm 3.2$ & 0.903 \\
\hline otal bilirubin (mmol/L) & $14.1(4.8-41.9)$ & $14.1(9.2-44.2)$ & 0.897 & $\begin{array}{c}13.5(5.0- \\
29.6)\end{array}$ & $\begin{array}{c}15.0(9.2- \\
44.2)\end{array}$ & 0.791 \\
\hline hild-Pugh score $(5 / 6 / 7)$ & $\begin{array}{c}62 / 10 / 1 \\
(84.9 / 13.7 / 1.4)\end{array}$ & $\begin{array}{c}40 / 2 / 0 \\
(95.2 / 4.8 / 0)\end{array}$ & 0.089 & $\begin{array}{c}38 / 2 \\
(95.0 / 5.0)\end{array}$ & $\begin{array}{c}38 / 2 \\
(95.0 / 5.0)\end{array}$ & 1.000 \\
\hline nour burden & & & & & & \\
\hline umour size $(\leq 5 />5 \mathrm{~cm})$ & $\begin{array}{c}45 / 28 \\
(61.6 / 38.4)\end{array}$ & $\begin{array}{c}32 / 10 \\
(76.2 / 23.8)\end{array}$ & 0.110 & $\begin{array}{c}30 / 10 \\
(75.0 / 25.0)\end{array}$ & $\begin{array}{c}30 / 10 \\
(75.0 / 25.0)\end{array}$ & 1.000 \\
\hline $\begin{array}{l}\text { lpha-fetoprotein } \\
00 />400 \mathrm{ng} / \mathrm{ml})\end{array}$ & $\begin{array}{c}46 / 27 \\
(63.0 / 37.0)\end{array}$ & $\begin{array}{c}30 / 12 \\
(71.4 / 28.6)\end{array}$ & 0.359 & $\begin{array}{c}28 / 12 \\
(70.0 / 30.0)\end{array}$ & $\begin{array}{c}28 / 12 \\
(70.0 / 30.0)\end{array}$ & 1.000 \\
\hline
\end{tabular}




\begin{tabular}{|c|c|c|c|c|c|c|}
\hline hortest margin $(\leq 2 />2$ & $\begin{array}{c}54 / 19 \\
(74.0 / 26.0)\end{array}$ & $\begin{array}{c}33 / 9 \\
(78.6 / 21.4)\end{array}$ & 0.580 & $\begin{array}{c}30 / 10 \\
(75.0 / 25.0)\end{array}$ & $\begin{array}{c}32 / 8 \\
(80.0 / 20.0)\end{array}$ & 0.592 \\
\hline lood loss $(\leq 400 />400$ & $\begin{array}{c}61 / 12 \\
(83.6 / 16.4)\end{array}$ & $\begin{array}{c}38 / 4 \\
(90.5 / 9.5)\end{array}$ & 0.406 & $\begin{array}{c}35 / 5 \\
(87.5 / 12.5)\end{array}$ & $\begin{array}{c}36 / 4 \\
(90.0 / 10.0)\end{array}$ & 1.000 \\
\hline lood transfusion (yes/no) & $0 / 73(0 / 100)$ & $\begin{array}{c}1 / 41 \\
(2.4 / 97.6)\end{array}$ & 0.365 & $\begin{array}{c}0 / 40 \\
(0 / 100.0)\end{array}$ & $\begin{array}{c}1 / 39 \\
(2.5 / 97.5)\end{array}$ & 1.000 \\
\hline urgery time (min) & $\begin{array}{c}150.0(65.0- \\
510.0)\end{array}$ & $\begin{array}{c}150.0(90.0- \\
300.0)\end{array}$ & 0.908 & $\begin{array}{c}150.0(65.0- \\
400.0)\end{array}$ & $\begin{array}{c}150.0(90.0- \\
300.0)\end{array}$ & 0.612 \\
\hline $\begin{array}{l}\text { ortal vein block time } \\
\text { n) }\end{array}$ & $15.0(0-28.0)$ & $15.0(0-30.0)$ & 0.507 & $13.0(0-28.0)$ & $14.6 \pm 8.2$ & 0.279 \\
\hline
\end{tabular}

*Mean \pm SD; **Number (\%); ***Median (Range)

ECOG: Eastern Cooperative Oncology Group

Table 2. Univariate and multivariate analysis of risk factors for overall survival and recurrence-free survival. 


\begin{tabular}{|c|c|c|c|c|c|c|c|c|c|c|c|c|}
\hline \multirow[t]{3}{*}{ Variables } & \multicolumn{6}{|c|}{ Overall survival } & \multicolumn{6}{|c|}{ Recurrence-free survival } \\
\hline & \multicolumn{3}{|c|}{ Univariate analysis } & \multicolumn{3}{|c|}{ Multivariate analysis } & \multicolumn{3}{|c|}{ Univariate analysis } & \multicolumn{3}{|c|}{ Multivariate analysis } \\
\hline & HR & $95 \% \mathrm{CI}$ & $\begin{array}{c}P \\
\text { value }\end{array}$ & HR & $\begin{array}{c}95 \% \\
\text { CI }\end{array}$ & $\begin{array}{c}P \\
\text { value }\end{array}$ & HR & $\begin{array}{c}95 \% \\
\text { CI }\end{array}$ & $P$ & HR & $\begin{array}{c}95 \% \\
\mathrm{CI}\end{array}$ & $P$ \\
\hline $\begin{array}{l}\text { Age (y) } \\
(\leq />50)\end{array}$ & 1.964 & $\begin{array}{l}0.783- \\
4.928\end{array}$ & 0.151 & & & & 2.160 & $\begin{array}{l}1.086- \\
4.297\end{array}$ & 0.028 & 3.173 & $\begin{array}{l}1.518- \\
6.631\end{array}$ & 0.002 \\
\hline $\begin{array}{l}\text { Gender, } \\
\text { (Female/male) }\end{array}$ & 1.439 & $\begin{array}{l}0.192- \\
10.755\end{array}$ & 0.723 & & & & 0.750 & $\begin{array}{l}0.229- \\
2.458\end{array}$ & 0.635 & & & \\
\hline $\begin{array}{l}\text { Liver cirrhosis, } \\
\text { (no/yes) }\end{array}$ & 1.459 & $\begin{array}{l}0.559- \\
3.804\end{array}$ & 0.440 & & & & 1.019 & $\begin{array}{l}0.515- \\
2.009\end{array}$ & 0.957 & & & \\
\hline $\begin{array}{l}\operatorname{PLT}\left(10^{9} / \mathrm{L}\right) \\
(\leq />100)\end{array}$ & 0.238 & $\begin{array}{l}0.079- \\
0.719\end{array}$ & 0.011 & 0.238 & $\begin{array}{l}0.079- \\
0.719\end{array}$ & 0.011 & 0.342 & $\begin{array}{l}0.118- \\
0.992\end{array}$ & 0.048 & & & \\
\hline $\begin{array}{l}\text { PT (sec) } \\
(\leq />14)\end{array}$ & 0.048 & $\begin{array}{l}0- \\
5829.225\end{array}$ & 0.610 & & & & 2.303 & $\begin{array}{l}0.548- \\
9.680\end{array}$ & 0.255 & & & \\
\hline $\begin{array}{l}\operatorname{ALT}(\mathrm{U} / \mathrm{L}) \\
(\leq />50)\end{array}$ & 1.191 & $\begin{array}{l}0.398- \\
3.565\end{array}$ & 0.755 & & & & 1.710 & $\begin{array}{l}0.799- \\
3.658\end{array}$ & 0.167 & & & \\
\hline $\begin{array}{l}\text { AST }(U / L) \\
(\leq />40)\end{array}$ & 1.563 & $\begin{array}{l}0.599- \\
4.073\end{array}$ & 0.361 & & & & 1.847 & $\begin{array}{l}0.902- \\
3.782\end{array}$ & 0.093 & & & \\
\hline $\begin{array}{l}\operatorname{ALB}(\mathrm{g} / \mathrm{l}) \\
(\leq />40)\end{array}$ & 0.715 & $\begin{array}{l}0.209- \\
2.455\end{array}$ & 0.595 & & & & 0.527 & $\begin{array}{l}0.229- \\
1.211\end{array}$ & 0.131 & & & \\
\hline $\begin{array}{l}\text { TBIL } \\
(\mathrm{mmol} / \mathrm{L}) \\
(\leq />20)\end{array}$ & 2.152 & $\begin{array}{l}0.775- \\
5.982\end{array}$ & 0.142 & & & & 1.688 & $\begin{array}{l}0.730- \\
3.899\end{array}$ & 0.211 & & & \\
\hline $\begin{array}{l}\mathrm{AFP}(\mathrm{ng} / \mathrm{ml}) \\
(\leq />400)\end{array}$ & 1.068 & $\begin{array}{l}0.410- \\
2.782\end{array}$ & 0.892 & & & & 0.836 & $\begin{array}{l}0.391- \\
1.788\end{array}$ & 0.643 & & & \\
\hline $\begin{array}{l}\text { Child-Pugh } \\
\text { score, }(5 / 6)\end{array}$ & 3.883 & $\begin{array}{l}0.855- \\
17.637\end{array}$ & 0.079 & & & & 3.068 & $\begin{array}{l}0.913- \\
10.313\end{array}$ & 0.070 & & & \\
\hline $\begin{array}{l}\text { Tumor size } \\
(\leq />5),(\mathrm{cm})\end{array}$ & 2.777 & $\begin{array}{l}1.148- \\
6.716\end{array}$ & 0.023 & & & & 2.928 & $\begin{array}{l}1.496- \\
5.729\end{array}$ & 0.002 & 4.205 & $\begin{array}{l}2.045- \\
8.648\end{array}$ & $<0.001$ \\
\hline $\begin{array}{l}\text { Shortest } \\
\text { margin }(\mathrm{cm}) \text {, } \\
(\leq 2 />2)\end{array}$ & 0.474 & $\begin{array}{l}0.139- \\
1.618\end{array}$ & 0.233 & & & & 0.782 & $\begin{array}{l}0.362- \\
1.737\end{array}$ & 0.549 & & & \\
\hline $\begin{array}{l}\text { Blood loss } \\
(\mathrm{ml}) \\
(\leq 400 />400)\end{array}$ & 1.255 & $\begin{array}{l}0.286- \\
5.513\end{array}$ & 0.763 & & & & 1.267 & $\begin{array}{l}0.304 \\
-5.275\end{array}$ & 0.745 & & & \\
\hline
\end{tabular}




\begin{tabular}{|c|c|c|c|c|c|c|}
\hline $\begin{array}{l}\text { Surgery time } \\
(\min ) \\
(\leq 180 />180)\end{array}$ & 1.058 & $\begin{array}{l}0.303- \\
3.691\end{array}$ & 0.929 & 0.744 & $\begin{array}{l}0.236- \\
2.352\end{array}$ & 0.615 \\
\hline $\begin{array}{l}\text { Portal vein } \\
\text { block time } \\
\text { (min), } \\
(\leq 15 />15)\end{array}$ & 0.541 & $\begin{array}{l}0.196- \\
1.489\end{array}$ & 0.234 & 0.877 & $\begin{array}{l}0.436- \\
1.762\end{array}$ & 0.712 \\
\hline $\begin{array}{l}\text { Subsequent } \\
\text { radical } \\
\text { treatment } \\
\text { (no/yes) }\end{array}$ & 0.507 & $\begin{array}{l}0.543- \\
3.448\end{array}$ & 0.507 & - & - & - \\
\hline $\begin{array}{l}\text { Segment } \\
\text { resection, } \\
(\mathrm{S} 5+6 / \mathrm{S} 6+7)\end{array}$ & 0.550 & $\begin{array}{l}0.219- \\
1.381\end{array}$ & 0.203 & 0.765 & $\begin{array}{l}0.391- \\
1.496\end{array}$ & 0.434 \\
\hline
\end{tabular}

PLT, platelet count; PT, prothrombin time; ALT, alanine aminotransferase; AST, aspartate aminotransferase; ALB, albumin; TBIL, Total bilirubin, AFP, alpha-fetoprotein; HR, hazard ratio, CI, Confidence intervals

Table 3. Postoperative serum level changes of liver function indicators 


\begin{tabular}{|c|c|c|c|}
\hline Time after surgery & S6+S5 Group $(n=40)$ & S6+S7 Group $(n=40)$ & $P$ Value \\
\hline \multicolumn{4}{|l|}{3 days } \\
\hline White blood cell $\left(10^{9} / \mathrm{L}\right)$ & $12.5(5.0-72.8)$ & $12.7(6.1-124.0)$ & 0.925 \\
\hline Haemoglobin (g/L) & $124.7 \pm 17.1$ & $126.8 \pm 12.2$ & 0.536 \\
\hline Platelet count $\left(10^{9} / \mathrm{L}\right)$ & $123.2 \pm 44.6$ & $127.0 \pm 50.2$ & 0.731 \\
\hline Prothrombin time (sec) & $14.0(12.6-16.9)$ & $14.6(13.5-18.4)$ & 0.071 \\
\hline Alanine aminotransferase (U/L) & $291.4(46.0-1265.0)$ & $320.9(114.4-997.2)$ & 0.739 \\
\hline Aspartate aminotransferase(U/L) (U/L) & $123.0(24-750.7)$ & $154(44.1-530.6)$ & 0.566 \\
\hline Serum albumin $(\mathrm{g} / \mathrm{L})$ & $36.6 \pm 3.6$ & $36.1 \pm 3.4$ & 0.542 \\
\hline Total bilirubin (mmol/L) & $24.1(8.7-107.8)$ & $24.7(9.2-111.0)$ & 0.486 \\
\hline \multicolumn{4}{|l|}{7 days } \\
\hline White blood cell $\left(10^{9} / \mathrm{L}\right)$ & $9.0(4.4-16.9)$ & $8.4(3.4-13.9)$ & 0.536 \\
\hline Haemoglobin $(\mathrm{g} / \mathrm{L})$ & $119.3 \pm 14.5$ & $119.5 \pm 11.1$ & 0.961 \\
\hline Platelet count $\left(10^{9} / \mathrm{L}\right)$ & $165.7 \pm 54.9$ & $174.8 \pm 76.1$ & 0.553 \\
\hline Prothrombin time (sec) & $13.2 \pm 0.7$ & $13.4(12.0-17.7)$ & 0.448 \\
\hline Alanine aminotransferase (U/L) & $109.3(29.7-378.3)$ & $113.5(36.2-364.7)$ & 0.987 \\
\hline Aspartate aminotransferase (U/L) & $40.0(18.9-104.6)$ & $43.0(15.5-127.1)$ & 0.306 \\
\hline Serum albumin $(g / L)$ & $38.2 \pm 3.8$ & $38.0(26.6-66.3)$ & 0.703 \\
\hline Total bilirubin (mmol/L) & $20.2 \pm 9.3$ & $22.1(10.8-80.9)$ & 0.257 \\
\hline \multicolumn{4}{|l|}{1 month } \\
\hline White blood cell (109/L) & $6.74 \pm 2.0$ & $5.9 \pm 2.2$ & 0.237 \\
\hline Haemoglobin $(\mathrm{g} / \mathrm{L})$ & $138.5 \pm 9.6$ & $137(116.0-157.0)$ & 0.783 \\
\hline Platelet count (109/L) & $162.7 \pm 56.1$ & $169.9 \pm 55.3$ & 0.696 \\
\hline Prothrombin time (sec) & $13.1 \pm 0.5$ & $12.3 \pm 1.3$ & 0.800 \\
\hline Alanine aminotransferase (U/L) & $27.3(15.0-55.0)$ & $30.8(7.6-128.1)$ & 0.527 \\
\hline Aspartate aminotransferase (U/L) & $28.3 \pm 6.9$ & $31.4(15.6-73.7)$ & 0.164 \\
\hline Serum albumin $(g / L)$ & $45.2(37.1-76.2)$ & $44.4 \pm 3.4$ & 0.475 \\
\hline Total bilirubin (mmol/L) & $11.8 \pm 3.7$ & $11.8(6.3-27)$ & 0.639 \\
\hline
\end{tabular}

Table 4. Initial recurrence of hepatocellular carcinoma after liver resection in propensity score-matched patients 


\begin{tabular}{lccc}
\hline Recurrence location & S6+S5 Group (N=20) & S6+S7 Group (N=12) & PValue \\
\hline Within 2 cm of cut edge cm & 3 & 4 & \\
Right lobe & 6 & 4 & \\
& & & \\
Left lobe & 4 & 2 & 0.754 \\
Whole liver & 4 & 2 & \\
Extrahepatic organ & 4 & 1 & \\
\hline
\end{tabular}

$\mathrm{cm}$, centimetre

\section{Figures}




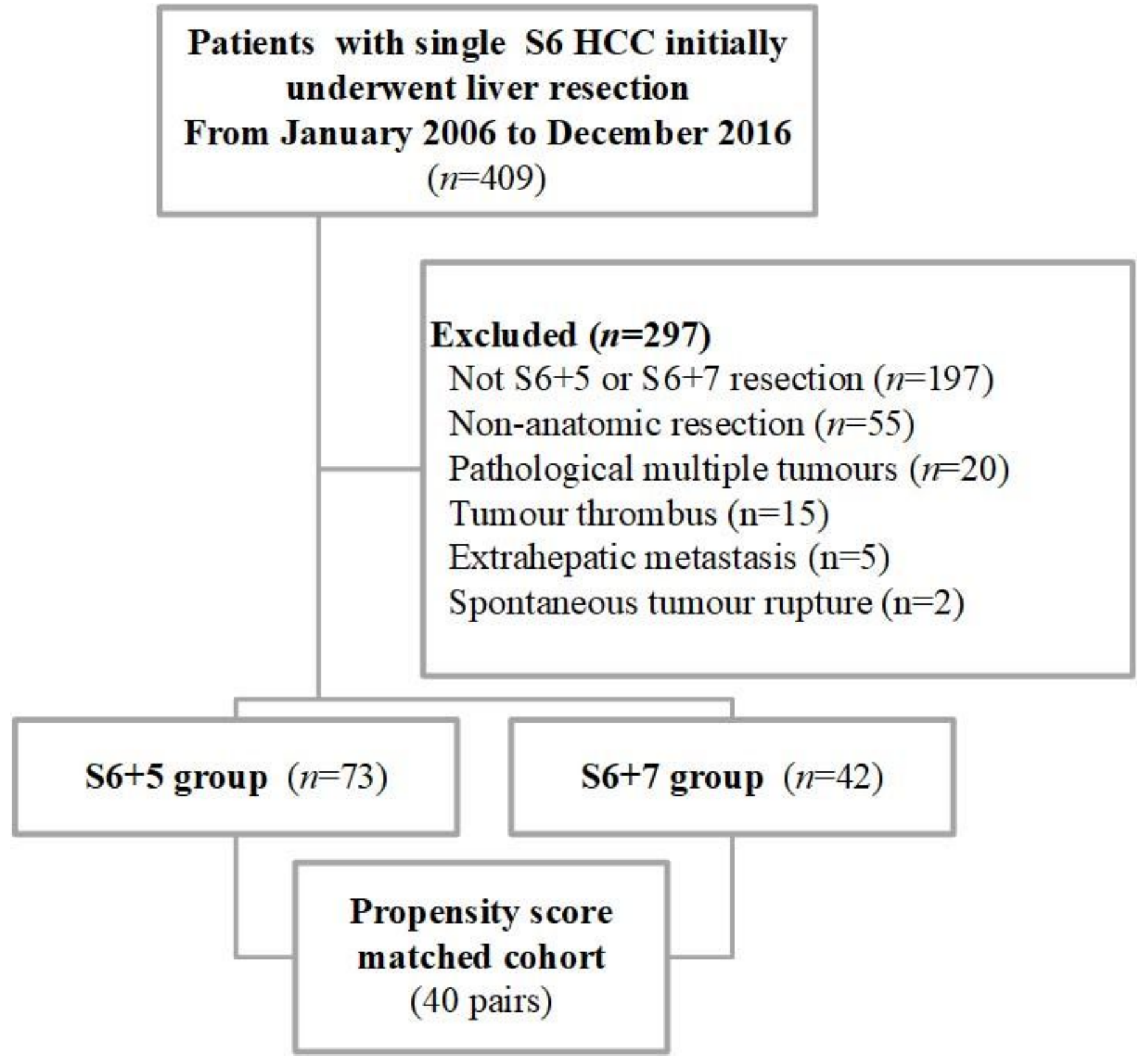

Figure 1

Patient selection algorithm chart 

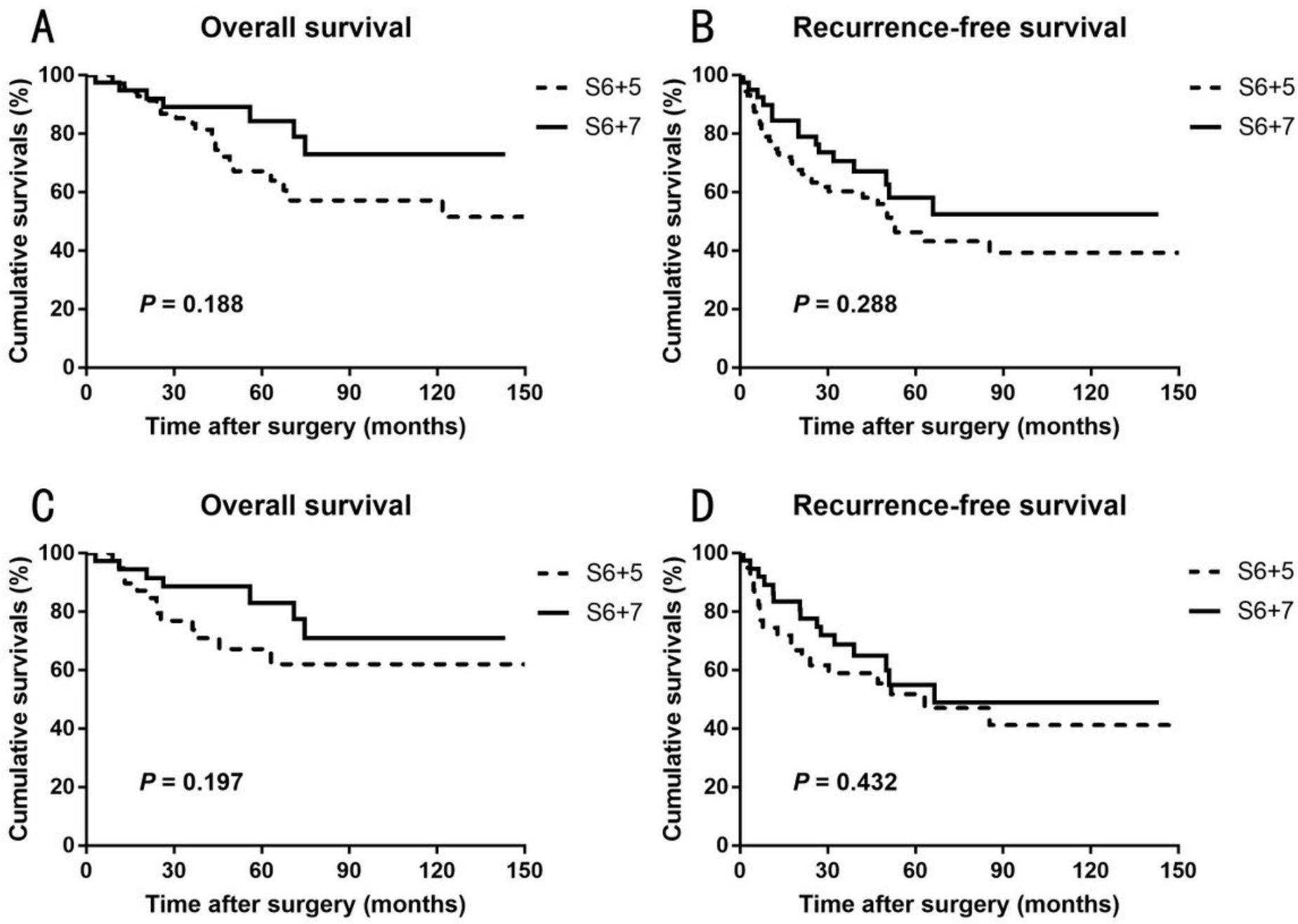

Figure 2

Kaplan-Meier curves of survival outcomes after hepatectomy of segment 6 hepatocellular carcinoma. (A) overall survival (OS) and (B) recurrence-free survival (RFS) in overall cohorts. (C) OS and (D) RFS in matched cohorts by PSM 